\title{
Educação não formal: cemitério como espaço público para o ensino da Geografia ${ }^{1}$
}

\author{
Non-formal education: cemetery as a public space for teaching Geography
}

\author{
Francisleile Lima Nascimento'; Pollyana Fontinelle Vilela"; \\ Maria Dutra Cardoso"III; Márcia Teixeira Falcão'v
}

\begin{abstract}
RESUMO
A presente pesquisa aborda a temática da morte através do cemitério (Cemitério Público Municipal Nossa Senhora da Conceição) como espaço público não formal para o ensino da geografia, com intuito de apresentar a necrópole como um objeto de estudo para os conhecimentos geográficos, tendo em vista que neste espaço há existência de diversos elementos sociais a serem considerados, tais como: a desigualdade social, segregação espacial, paisagens urbanas entre outros. Tem como objetivo apresentar, através da metodologia de aula de campo, que o cemitério pode ser utilizado como um lugar não formal para o aprendizado geográfico, destacando o uso de ferramentas tecnológicas, a produção de material didático como maquetes e croquis. A pesquisa parte de uma revisão bibliográfica, fazendo uso da pesquisa exploratória e explicativa, a partir da abordagem qualitativa, onde os procedimentos para a coleta de dados se dão através da análise de conteúdo (necrópole e geografia). Dessa forma, a pesquisa mostra que o ambiente público não formal do cemitério pode e deve ser explorado pelo docente de geografia oportunizando ao alunado a possibilidade do desenvolvimento de habilidades que favoreçam as diversas aprendizagens.
\end{abstract}

Palavras-chave: Espaço não formal; Educação; Cemitério; Ensino de geografia

\section{ABSTRACT}

This research addresses the theme of death through the cemetery (Municipal Public Cemetery Nossa Senhora da Conceição) as a non-formal public space for the teaching of geography, in order to present the necropolis as an object of study for geographic knowledge, with a view to that in this space there are several social elements to be considered, such as: social inequality, spatial segregation, urban landscapes, among others. It aims to present, through the field class methodology, that the cemetery can be used as a non-formal place for geographic learning, highlighting the use of technological tools, the production of didactic material such as models and sketches. The research starts from a bibliographic review, making use of exploratory and explanatory research, from the qualitative approach, where the procedures for data collection are through content analysis (necropolis and geography). In this way, the research shows that the non-formal public environment of the cemetery can and should be explored by the geography teacher, giving the students the opportunity to develop skills that favor the various learnings.

Keywords: Non-formal space; Education. Cemetery; Geography teaching

\footnotetext{
${ }^{1}$ Artigo Científico apresentado como requisito obrigatório para conclusão do Curso de Pós-graduação em Especialização em Geografia com Ênfase no Ensino pela Universidade Estadual de Roraima (UERR).

I Universidade Estadual de Roraima RO, Brasil - https://orcid.org/0000-0002-8184-6176 - mdcardoso0707@gmail.com

" Universidade Estadual de Roraima RO, Brasil - https://orcid.org/0000-0002-9989-6796 - pollyanamestrado@gmail.com

II' Universidade Estadual de Roraima RO, Brasil - https://orcid.org/0000-0001-8604-5274 - mdcardoso0707@gmail.com

Iv Universidade Estadual de Roraima, RO, Brasil - https://orcid.org/0000-0003-3190-3192 - marciafalcao.geog@uerr.edu.br
} 


\section{INTRODUÇÃO}

Compreendendo que a educação é uma etapa de suma importância no desenvolvimento do indivíduo, pois ela contribui para a formação cognitiva e social, e marca sua vida escolar. O atual cenário da educação brasileira levanta diversos debates sobre o processo de ensino e aprendizagem, levando-nos a repensar as metodologias a serem aplicadas para proporcionar uma educação que contemple, de fato, o conhecimento e a formação integral do aluno (SILVA et al., 2016).

A educação necessita ter suas práticas educativas contempladas no currículo (Curriculares Nacionais - PCNs, as Diretrizes Curriculares Nacionais Gerais da Educação Básica - DCNs e a Base Nacional Comum Curricular - BNCC) voltado para o desenvolvimento e habilidades dos alunos, no sentido de favorecerem as diversas aprendizagens, no ensino da Geografia suas habilidades e competências estão voltada para o ensino da relação entre a sociedade e a natureza.

A presente pesquisa aborda o ensino da geografia a partir dos espaços não formais. Para este ensaio, utilizamos como recorte espacial o cemitério, por se tratar de um espaço público que envolve a inter-relação dos contextos sociais, culturais, políticos e econômicos que atravessam o momento da morte, mostrando que o ensino pode e deve romper as barreiras das quatro paredes da sala de aula.

Partindo do pressuposto que o aluno pode analisar o cemitério como um espaço de relações entre a sociedade e a natureza, a pesquisa surge em decorrência de questionamentos, experiências vividas através das práticas de trabalhos de campo em cemitérios, aplicando metodologias que envolvem a educação geográfica (ou o ensino de geografia). Frente a esse desafio, a pesquisa justifica-se nos âmbitos sociais e acadêmico- científico:

A pesquisa torna-se relevante para o aspecto social, pois tem a intenção de despertar o olhar sóciogeográfico do corpo acadêmico e escolar para temáticas que até então são vistas apenas de uma perspectiva (a morte), como ocorre com o cemitério que se resume em um espaço para receber e depositar os cadáveres. 
Entretanto, quando visto sob a ótica geográfica pode-se despertar a concepção de revelar as relações sociais, culturais, políticas, econômicas, ambientais e que retrata a desigualdade social, segregação espacial, entre outros aspectos.

A justificativa acadêmico-científico para o desenvolvimento da presente pesquisa reside em lacunas sobre estudos cemiteriais no Brasil, e principalmente no estado de Roraima, pois é um tema timidamente estudado no âmbito regional. Dessa forma, a pesquisa será um marco nas questões relacionadas às necrópoles e servirá como balizador para futuros pesquisadores contribuindo com os estudos de (PACHECO, 2012; LEON LUCAS, 2006, NASCIMENTO, 2019).

Apesar de não ser uma pesquisa inédita, o estudo visa associar e relacionar o ensino de geografia dentro e fora de sala de aula, utilizando aulas práticas a partir da metodologia de aula de campo, utilizando de ferramentas tecnológicas, e materiais didáticos que podem ser produzidos com enfoque nas necrópoles².

A partir destas metodologias é possível levar o aluno a perceber que o cemitério é um espaço público não formal que pode ser compreendido através de técnicas e análises a partir do ensino de geografia.

A escolha do tema deve-se a ausência de preocupação e um olhar atípico sobre as necrópoles além de um espaço de morte. A pesquisa questiona - Como o cemitério pode ser objeto de estudo da geografia de maneira que esse conteúdo possa ser explorado e contextualizado com o saber geográfico dentro e fora de sala de aula? Como associar a educação não formal com os conhecimentos da geografia? É possível associar a educação não formal com os conhecimentos geográficos a partir do cemitério como objeto de estudo?

Dentre os objetivos específicos deste ensaio, destaca-se: apresentar, através da metodologia de aula de campo, que o cemitério pode ser utilizado como um espaço público não formal para o ensino da geografia; destacar as ferramentas tecnológicas

\footnotetext{
${ }^{2}$ Necrópoles ou os cemitérios é o lugar ou espaço reservado para cultuar a memória de uma determinada comunidade, povo ou grupo de forma que a sua contemplação evoca e fortalece os laços entre os vivos e os mortos. Eram constituídos como lugares de convívios dos vivos para celebrarem suas principais atividades sociais concebidos como espaço com função civil e principalmente religiosa, por esse motivo seus espaços ocupavam os terrenos das igrejas em formatos quadrangulares e fechado, espaço característico das cidades e aldeias medievais (FARGETTE-VISSIËRE, 2009).
} 
que podem ser aplicadas em sala de aula utilizando a necrópole como lugar público não formal para os conhecimentos geográficos; e descrever os materiais didáticos que podem ser produzidos utilizando o cemitério como ambiente público não formal para o ensino e aprendizado da ciência geográfica.

Conforme Gil (2008, p. 42), a pesquisa é um meio pelo qual o pesquisador objetiva a descoberta de resposta para problemas por meio de procedimentos científicos, caracterizado como pragmático, por ser um apresentar "processo formal e sistemático de desenvolvimento do método científico". Neste contexto, essa pesquisa servirá como resposta às lacunas de conhecimento sobre a aplicação do ensino da geografia acerca da morte envolvendo a temática de cemitério que é o recorte espacial de estudo desta pesquisa.

Cabe ressaltar a necessidade de se produzir mais pesquisas e realmente ter a percepção de que o cemitério é um lugar que deve ter atenção não somente do poder público, é um campo também de diversos estudos podendo ser utilizado como espaço não formal de educação, neste caso em especial para o ensino de geografia. A pesquisa contribui ainda com os grupos de pesquisa do Núcleo Amazônico de Pesquisas em Relações Internacionais (NAPRI); Interdisciplinaridade, Comunicação e Políticas Públicas da Universidade Federal de Roraima (UFRR).

Sendo assim, como Geógrafa e pesquisadora, essa temática sobre as necrópoles é desenvolvida desde 2013 com produções realizadas e publicadas através monografia, dissertação e artigos. É um tema de extrema importância ao qual proporcionará uma visão holística que possibilitará a compreensão e discussões mais abrangentes acerca das necrópoles em nível regional.

A pesquisa encontra-se organizada em tópicos. O primeiro tópico refere-se à introdução com a apresentação da temática, problematização, objetivos e metodologia. O segundo tópico aborda os principais conceitos e concepções da educação formal e educação não formal mostrando a diferença entre elas. O terceiro apresenta uma reflexão sobre os espaços não formais, educação, ciência e cultura, 
com destaque para a contextualização do processo educacional, a produção científica e os aspectos culturais nestes espaços.

O quarto tópico faz uma abordagem do cemitério e sua relação com os espaços públicos e educação, apresentando as necrópoles a partir de uma breve abordagem conceitual e histórica, bem como os espaços públicos destacando a compreensão da educação através da cidade. O quinto tópico corresponde aos procedimentos metodológicos apresentando as técnicas e métodos aplicados na pesquisa. O sexto tópico trata-se da análise e discussão dos resultados, apresentando assim o cemitério como espaço público não formal de educação, refletindo sobre o ensino da geografia e o desenvolvimento crítico do indivíduo, abordando as práticas metodológicas para o ensino de geografia com destaque para a aula de campo, o uso de ferramentas tecnológicas, e a construção de material didático como a confecção de maquetes e desenhos (croquis). Por fim, são apresentadas as considerações finais.

\section{EDUCAÇÃO FORMAL E EDUCAÇÃO NÃO FORMAL}

Conforme Cascais e Terán (2014) pode-se compreender a educação formal e não formal pelos seguintes aspectos:

Os termos, formal, não formal e informal são de origem anglosaxônica, surgidos a partir de 1960. Vários fatores, ocasionados pela segunda Guerra Mundial, desencadearam uma crise educacional nos países do primeiro Mundo, dentre eles: a) os sistemas escolares não conseguiam atender à grande demanda escolar, b) os sistemas escolares não cumpriam seu papel em relação à promoção social e, c) a não formação de recursos humanos para as novas tarefas que surgiam com a transformação industrial. Com isso, ocorreu, de um lado, a exigência de um planejamento educacional e, de outro, a valorização de atividades e experiências não escolares, tanto ligadas à formação profissional quanto à cultura geral

A educação formal é o ensino ofertado e desenvolvido pela escola que compreende um conjunto de conteúdos curriculares que apresenta uma 
intencionalidade previamente estipulada dentro de uma proposta curricular marcada pelas práticas pedagógicas (GOHN, 1998).

Quanto à educação não formal, Gohn (1998) menciona que se trata do ensino ofertado por outras entidades que visam preencher as lacunas deixadas pela escola quando esta não consegue atender a todas as demandas atuais. Este processo formativo faz uso de diversos métodos, procedimentos e sistemas (ações educativas, aulas de campo, visita técnicas, pesquisas experimentais, entre outros) que vão além dos padrões da educação formal.

O contexto, da educação não formal no sistema de ensino no Brasil, se estabelece com a proclamação da República e com a Constituição Federal, onde o ensino passa a priorizar o ensino infantil, e o país determina essa modalidade educacional como a essencial para a Educação Básica, deixando assim, de ser compensatório e assistencial, passando a integrar a um projeto educacional que visa à formação integral da criança contemplando a contextualização das práticas pedagógicas da educação não formal (CURY, 2002).

Sendo assim, a educação não deve ser vista como um processo isolado, visto que o aprendizado tem desde o início da humanidade com sua base predominantemente nas relações sociais que envolvem a educação formal (escola) e educação informal (família) (CURY, 2002).

Partindo desse princípio e considerando a contextualização da educação formal e informal, os sistemas de ensino no Brasil somente se desenvolvem de fato com o processo de descentralização e da democratização das escolas públicas ocorridas em meados dos anos 1980, impulsionado pelas reformas educacionais, pelas discussões e debates na câmara legislativa no sentido de institucionalizar o ensino (CURY, 2002).

\section{ESPAÇOS NÃO FORMAIS: EDUCAÇÃO, CIÊNCIA E CULTURA}

A diferenciação do termo espaço formal, não formal e informal de ensino é relacionado ao âmbito escolar. "Assim, ações educativas escolares seriam formais e 
aquelas realizadas fora da escola não formais e informais" (MARANDINO; SELLES; FERREIRA, 2009, p. 133).

A compreensão de espaço não formal seria o inverso do espaço formal. Quando contextualizado ao âmbito educacional e concebido como espaço formal de educação e espaço não formal de educação, têm-se como primeiro a escola sendo um espaço institucionalizado e normatizado a partir da matriz curricular e uma infraestrutura para receber o aluno e direcionar um ensino convencional. O segundo seria os espaços diferentes da escola que promovem ou desenvolvem atividades educativas, a exemplo dos programas sociais e culturais (JACOBUCCI, 2008).

Figura 01 - Categorias de espaços não formais

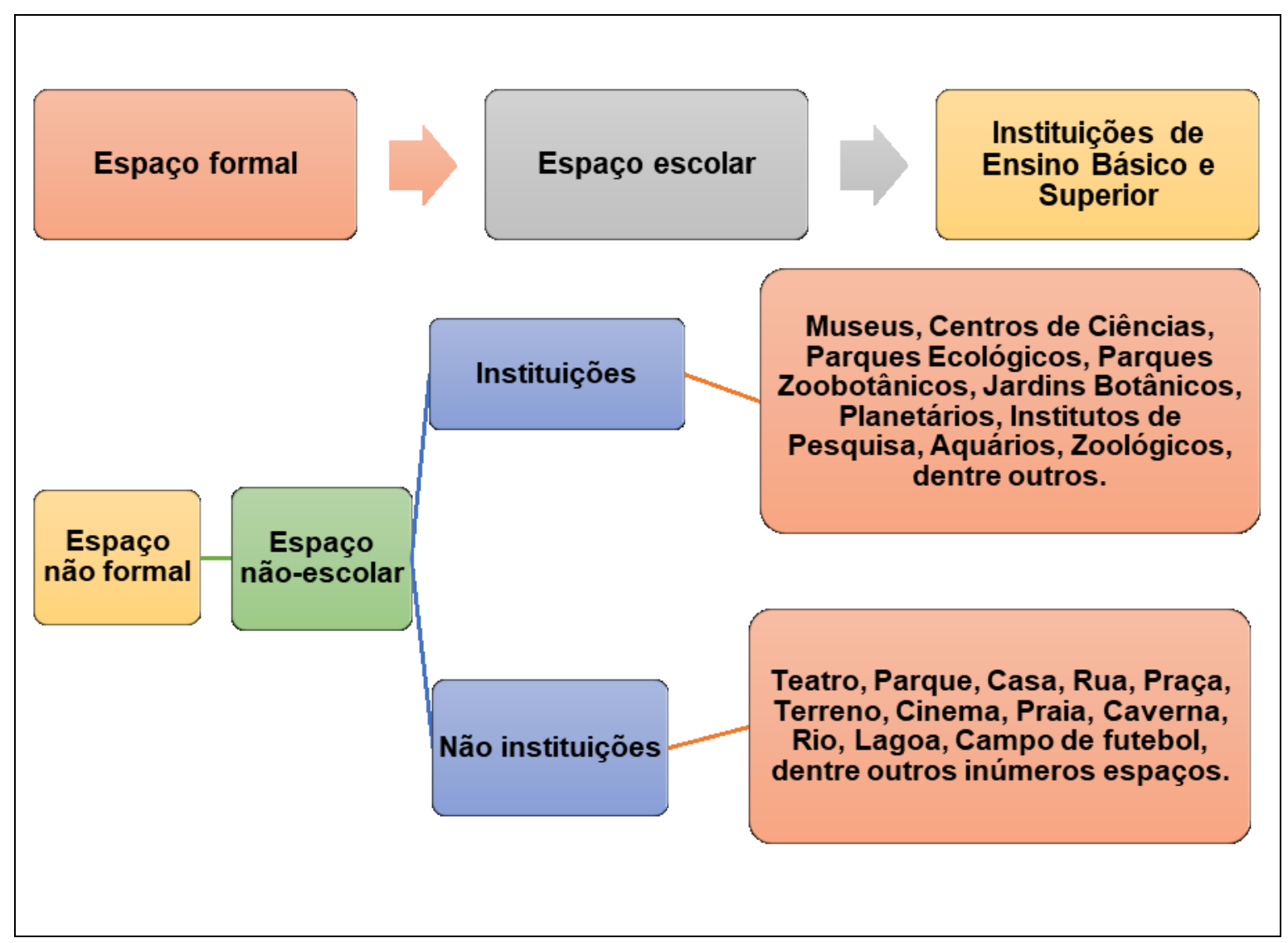

Fonte: organização autoral a partir de (MOURA, 2005)

Segundo Moura (2005) os espaços não formais podem ser classificados em duas categorias: os espaços não formais que são instituições e espaços não formais que não são instituições, conforme será ilustrado na Figura 1. 
Partindo desse princípio pode-se conceber os espaços não formais como sendo aqueles que proporcionam educação, desenvolvimento da ciência e cultura, regulamentados e constituídos de infraestrutura técnica, que disponibilizam atividades programadas e executadas para esses fins educativos (JACOBUCCI, 2008).

Enquanto que os espaços não formais de categoria não institucional, são aqueles espaços naturais e urbanos, ao qual não disponibilizam de estrutura institucional, voltadas para as práticas educativas como os diversos espaços que o campo e a cidade dispõem, como exemplo, o cemitério ao qual é o foco de estudo dessa pesquisa concebido como espaço público não formal para o ensino (VAINE; LORENZETTI, 2017).

\section{CEMITÉRIO, ESPAÇOS PÚBLICOS E EDUCAÇÃO}

Em ambientes de morfologias laicizadas3, os cemitérios apresentam características familiares de suas residências e de seus proprietários. Esses aspectos podem ser observados em Martini et al., (2018) quando frisa que o cemitério é uma extensão da vida social, lugar reservado para guardar as memórias dos mortos e preservar a história dos vivos.

Nessa perspectiva, os cemitérios tornam-se espaços públicos não formais que estão à disposição como objeto de estudo da educação não formal para a compreensão ou extensão da vida social, bem como o processo cultural de segregação do espaço

\subsection{Necrópoles: breves abordagens conceituais}

O conceito de cemitério a partir de sua terminologia surge do grego koimetérion, "dormitório", pelo latim Coemeteriu, significava o lugar onde se dorme quarto, dormitório. Esse significado é explicado pela mitologia grega, segundo a qual dormir

\footnotetext{
${ }^{3}$ Tornar leigo ou laico; retirar a influência religiosa de; atribuir caráter laico a alguma coisa: é necessário laicizar algumas instituições educacionais. Disponível em: https://www.dicio.com.br/laicizar/. Acesso em: 19 dez. 2019.
} 
(perder o conhecimento ou a consciência) é algo decidido por Hipno, deus grego do sono, o qual não tem o poder de fazer despertar. Hipno, segundo os gregos, era irmão gêmeo de Thanatos, o deus da morte (PACHECO, 2012).

De acordo com Pacheco (2012), a palavra cemitério, durante muito tempo, pertenceu à linguagem erudita dos clérigos (sujeito que faz parte da classe eclesiástica - clero), sendo os termos "galeria" e "carneiro" os mais antigos para designar o lugar da inumação (sepultamento ou enterramento ou a colocação de cadáver em sepultura, jazido ou local de consunção aeróbia) de cadáveres.

Dicionários da Língua Portuguesa dão à palavra cemitério outros significados afins: terreno descoberto em que se enterram ou guardam defuntos; luar onde a morte faz muitas vítimas; luar onde existem muitos objetos deteriorados, destruídos; região insalubre, epidêmica e onde se morre muito (PACHECO, 2012).

No cenário da escala temporal, os períodos civilizatórios acerca das necrópoles, como hoje são conhecidos, surgiram da necessidade de "melhorar a qualidade de vida nos centros urbanos". Foi a partir do século XVIII que começaram a se distanciar os mortos dos vivos, evitando, assim, doenças como cólera e peste bubônica.

Foi na chamada "belle époque" período iniciado por volta de 1880 e que se prolongou até 1914, que a arte europeia se revigorou. Nos cemitérios mais antigos, é comum encontrar trabalhos de artistas famosos, abrigando os restos de anônimos abastados. Em alguns casos, os mausoléus são verdadeiras obras de valor estético, alvos de visita e turismo (LEON LUCAS, 2006, p. 11-12).

O cemitério passou a existir por vários motivos para que assim, se tornasse obrigatório realizar sepultamento de mortos em áreas específicas para isso, as quais são conhecidas como cemitérios. No que diz respeito à prática funerária mais utilizada, tem sido o enterro em sepulturas, onde o caixão é assentado em contato direto com o solo (NASCIMENTO, 2019c).

Com base nas relações antrópicas no espaço geográfico a partir do surgimento das cidades dos mortos (necrópoles) e a preocupação com os centros urbanos é salutar discutir conceitos sobre urbanização e o processo de 
crescimento urbano ao longo das civilizações. Soma-se a isto, um fator importante que colaborou para a criação de cemitérios coletivos a céu aberto. Foi à urbanização acelerada e o crescimento das cidades, tendo em vista que o crescimento populacional em grande proporção não permitia mais que os sepultamentos fossem nas capelas e igrejas, pois estas já não comportavam o aumento da demanda de mortos (NASCIMENTO, 2019c).

\subsection{Espaços públicos: a educação através da cidade}

A cidade é o lugar dos encontros, do novo e do velho através das lutas sociais que definem o papel de cada um nesse processo de construção da sociedade. A cidade torna-se nesse sentido o lugar onde há interação social dos que atuam e dos que estão na reserva lutando por oportunidades (SANTOS, 1987).

Logo, esse espaço sofrerá a ação da segregação onde muitos desses atores sociais jamais serão chamados para atuar. Estes são os que jamais se sentirão como cidadãos nesse espaço, seu lugar de destino serão os lugares afastados, sem condições mínimas de sobrevivência (GOHN, 2011).

Contudo, é necessário ver a cidade com outra visão, não mais a de que é o lugar onde está concentrada a grande parte da população de uma determinada região. A cidade é história viva construída ao longo do tempo, e ela se faz de todas as relações sociais (CALDEIRA, 2000).

Portanto, compreender o espaço como a produção humana em um ritmo frenético e em constante transformação, sendo construído, hierarquizado e dividido em classes, as cidades se fazem de homens que, constroem sua própria história se materializando através de sua existência (SANTOS, 1987).

Dessa forma, a cidade concebida como objeto de estudo da geografia possibilita o desenvolvimento de diversos saberes e conhecimentos sociais, políticos, econômicos, culturais e históricos impregnados em seus diversos espaços públicos. 


\section{PROCEDIMENTOS METODOLÓGICOS: TÉCNICAS E MÉTODOS}

A pesquisa se desenvolveu com base em uma leitura multidisciplinar comandada principalmente pelas fundamentações teóricas de (Pacheco, 2012; Leon Lucas, 2006, Nascimento, 2019c; Lima, 2002; Castrogiovanni, 2007; Tomita, 1999; Klimek, 2007) com intuito de analisar o ensino da geografia, a espacialização das ciências geográficas, a educação não formal e o cemitério como espaço público não formal para o ensino.

A pesquisa faz uso do método de abordagem (dedutivo, indutivo, dialético, hipotético-dedutivo).

O Método dedutivo, "parte de princípios reconhecidos como verdadeiros e indiscutíveis e possibilita chegar a conclusões de maneira puramente formal, isto é, em virtude unicamente de sua lógica" (GIL, 2008, p. 9).

Dessa forma, a pesquisa faz uso da dedução considerando a existência de verdades gerais já afirmadas que servem de premissa para se chegar, por meio dela, a novos conhecimentos.

Para Lakatos e Marconi (2007) o método indutivo consiste em:

Um processo mental por intermédio do qual, partindo de dados particulares, suficientemente constatados, infere-se uma verdade geral ou universal, não contida nas partes examinadas. Portanto, o objetivo dos argumentos indutivos é levar a conclusões cujo conteúdo é muito mais amplo do que o das premissas nas quais se basearam (LAKATOS; MARCONI, 2007, p. 86).

Quanto à indução o estudo visa partir de uma cadeia de raciocínio particular para o geral. Com relação ao método dialético a pesquisa busca o confronto das ideias proporcionando o desenvolvimento de novos saberes.

Nesse sentido, o método hipotético-dedutivo vem contribuir no sentido lógico relacionado com a experimentação, motivo pelo qual é bastante usado no campo das pesquisas das ciências naturais (MARCONI; LAKATOS, 2006).

Utiliza-se da pesquisa exploratória e explicativa. O estudo parte da pesquisa exploratória para proporcionar maior familiaridade com o problema por meio do 
levantamento bibliográfico. A pesquisa explicativa vem atender a complexidade do estudo quanto a realidade pesquisada (GIL, 2008). Faz uso do método qualitativo para verificar a relação da realidade com o objeto de estudo, obtendo várias interpretações de uma análise indutiva por parte do pesquisador (RAMOS; RAMOS; BUSNELLO, 2005).

A pesquisa é direcionada aos alunos do Ensino Fundamental II (6 $6^{\circ}$ ao $9^{\circ}$ Ano) e Ensino Médio $\left(1^{\circ}, 2^{\circ}\right.$ e $3^{\circ}$ ano) na disciplina de Geografia.

A pesquisa bibliográfica constitui publicações em forma de artigos, livros, revistas, teses, dissertações entre outros. A pesquisa parte de uma revisão bibliográfica importante para todo trabalho acadêmico, pois são os aportes teóricos que vão embasar e dar credibilidade à pesquisa, tornando-a um trabalho científico (GIL, 2008).

Por se tratar de uma pesquisa de abordagem qualitativa, os procedimentos para a coleta de dados dar-se-á através da análise de conteúdo. A análise de conteúdo designa a técnica de investigar e interpretar de forma sistematizada os dados coletados. Sendo assim, a análise de conteúdo possibilita diferentes modos de conduzir o processo de interpretação (BARDIN, 2011).

A análise dos dados ocorre mediante a análise bibliográfica comparativa dos estudos científicos de forma hipotético-dedutiva e exploratória observacional, comparando os resultados de pesquisas já publicadas confrontando com o embasamento bibliográfico para atenuar e testificar os resultados da pesquisa (MARCONI; LAKATOS, 2006).

Cabe mencionar que a pesquisa faz uso da técnica de maquetes e croquis para demonstrar a construção de material didático apresentado como resultados da prática metodológica aplicada. Silva e Muniz (2008, p. 67) enfatizam que "incentivar o aluno a produzir maquetes permite uma participação maior deste no processo de aprendizagem, além de dar oportunidade ao educador para perceber o contexto sociocultural em que os estudantes estão inseridos". Quanto ao croqui Miranda (2005, p. 57) menciona que "o desenho serve para fazer geografia como método de 
abordagem e de análise, como investigação da paisagem através de confrontações entre o assunto observado (e não o modelo) e os traçados que resultam da análise".

\section{ANÁLISE E DISCUSSÃO DOS RESULTADOS}

\subsection{Cemitério como espaço público não formal de educação}

Os cemitérios como hoje são conhecidos, surgiram da necessidade de "melhorar a qualidade de vida nos centros urbanos". Dessa forma, o cemitério torna-se um lugar de extrema importância para o planejamento urbano, além de representar todo um contexto de extensão da vida social do morto (LEON LUCAS, 2006, p. 11-12).

Dessa forma, quando se refere o cemitério quanto espaço público não formal Nascimento (2019c) menciona que o mesmo se encaixa na concepção de espaço não formal que não são instituições. Todavia, por apresentar diversas leituras históricas, sociológicas, filosóficas, geográficas e culturais, esse espaço público surge como uma fonte riquíssima de conhecimento que ultrapassa o conceito de lugar para guardar os cadáveres.

Sendo assim, quando os cemitérios são analisados sobre essas diversas leituras, é possível perceber o processo de segregação espacial, divisão de classe, divisão social de renda, contexto cultural, entre outros aspectos que podem ser explorados pela educação não formal e contribuir com a formação dos alunados.

\subsection{0 ensino da geografia e o desenvolvimento do pensamento crítico do indivíduo}

Para iniciar a análise sobre o ensino da Geografia, é importante compreender que, segundo Lima (2002, p. 58) essa é uma ciência que nasceu do anseio do homem em conhecer e registrar o espaço onde mora para desenvolver com precisão suas atividades diárias, fato que marca o aparecimento da Geografia tradicional.

Com relação ao desenvolvimento da disciplina de Geografia, Castrogiovanni (2007) ressalta que, no decorrer dos anos, a disciplina agregou um contexto de 
interdisciplinaridade e acabou por ser confundida por ramificações que ela mesma incorpora como é o caso da Educação Ambiental, Climatologia entre outros.

De acordo com Silva (2004), a concepção do ensino da Geografia sofreu também influência dos saberes matemáticos enraizados pelos conhecimentos da Astronomia, Cosmografia, Cartografia e Geometria, "tornando a disciplina um estudo decorativo". Para Tomita (1999) o ensino da Geografia, ao longo do tempo foi encarada como uma ciência de descrições e de informações, por isso, para ser professor de Geografia, necessitava-se de uma extraordinária memória e ter capacidade de reter exaustivos dados numéricos, nomes de cidades, montanhas, rios e outros. Esse saber era repassado (informado) aos seus alunos no decorrer da aula.

Entretanto, quando se refere ao desenvolvimento crítico do indivíduo com relação ao saber geográfico, Ferreira et al., (2011) destacam que a Geografia vem sofrendo mudanças, procurando pensar qual é o seu papel na sociedade, constituindo-se de novos conteúdos, reformulando outros de grande importância já existentes, questionando os métodos utilizados para explicar os conteúdos e utilizando novos métodos, fazendo com que os alunos participem mais das aulas com questionamentos e vivências do dia a dia.

Dessa forma, Santos (2001) enfatiza que o conteúdo aplicado precisa ser contextualizado com a vida do aluno.

Toda aprendizagem precisa ser significativa para o aluno (não mecanizada), ou seja, deve estar relacionada com conhecimentos, experiências e vivências do aluno, permitindo-lhe formular problemas e questões de interesse, entrar em confronto experimental com problemas práticos relevantes, participar do processo de aprendizagem e transferir o que aprendeu para outras situações da vida (SANTOS, 2001, p. 71).

Percebe-se assim, que o pensamento crítico do indivíduo é constituído mediante seu convívio com o meio que o cerca. Dessa forma, os Parâmetros Curriculares nacionais - PCN's (1997) afirmam que o ensino da Geografia proporciona o conhecimento contextualizado entre homem e natureza, bem como, suas ações e 
consequências sobre o meio natural, oportunizando grandes possibilidades de o aluno conceber seu próprio conceito a respeito da compreensão e da relação de sociedade e natureza.

Diante do exposto, Klimek (2007) destaca que:

O ensino de Geografia deve possibilitar ao aluno a compreensão da realidade e instrumentalizá-lo para que faça leitura crítica, identifique problemas e estude caminhos para solucioná-los; mas para isso é necessário que os alunos e o professor sejam parceiros na busca de conhecimento e saibam utilizá-los de forma a entender o espaço e analisá-los geograficamente para estabelecer relações, associações entre o lugar e o mundo (KLIMEK, 2007, p. 119).

Percebe-se, nesse sentido, que Geografia tem um peso extraordinário na formação do cidadão, visto que a mesma possibilita vários olhares de um mesmo conteúdo, levando o aluno à compreensão e à leitura crítica. Castrogiovanni (2000, p. 152) afirma que "com isso a Geografia pode sim desvelar (tirar véus), coisas que estão encobertas. Não no sentido de mostrar agora o lado 'real', 'correto' das coisas. Mas, simplesmente, mostrar que sempre há mais de uma leitura possível".

Se a Geografia é uma ciência que proporciona uma visão ampla do conhecimento, para Passerini (2007) o professor tem liberdade para ensinar o saber geográfico em várias facetas, fazendo uso de diversos recursos, entre eles os que estão presentes no cotidiano do aluno, levando-o a fazer novas descobertas, como ocorrem com os métodos tecnológicos educacionais.

\subsection{Práticas metodológicas para o ensino de geografia}

Como práticas metodológicas para o ensino geográfico destaca-se a aula de campo. Monezi e Filho (2005) afirmam que a aula de campo permite ao discente o contato com a aplicação prática dos conteúdos aprendidos em sala de aula por isso, a referida prática é de fundamental importância como ferramenta no processo de ensino-aprendizagem, estabelecendo um apoio e auxílio na condução da aula. 
Diante desse contexto, dar aula fora da sala é perceber que os alunos quando tem contato direto com o objeto de estudo através da aula de campo passam a conceber um entendimento melhor sobre o conteúdo estudado. Conforme Costa e Araújo (2012), o desenvolvimento da aula de campo proporciona uma interação entre o ensinamento teórico e prático, o que é de fundamental importância para o aluno aprofundar seu conhecimento e expressar seu pensamento crítico em sala de aula. Outro fator importante da aula de campo como metodologia de ensino da Geografia é o interesse e o entusiasmo dos alunos em participar das aulas, visto que essa metodologia quebra as barreiras do ensino tradicional, abrindo margem para um ensino mais dinâmico e atrativo.

A metodologia das aulas de campo tem sido bastante utilizada por possibilitar a interdisciplinaridade, principalmente no ensino superior como meio de relacionar a teoria com a prática. Essa didática promove a reflexão sobre o estudo de novos recursos metodológicos que possam contribuir na formação dos futuros profissionais que irão utilizar o espaço geográfico para desenvolver estudos e pesquisas.

As aulas de campo tornaram-se importante para o desenvolvimento da percepção ambiental, pois possibilita que os docentes possam rever os conceitos teórico-metodológicos, promovendo entre seus alunos o diálogo produzido em sala de aula com a realidade descrita por meio da paisagem geográfica, conhecida a partir de observações feitas no desenvolvimento técnico-científico e reforçada pelo método da visita técnica (MOURA, 2008).

Nota-se que as aulas de campo produzem uma abertura maior para o educando formular e conceber seus conceitos a respeito da percepção ambiental. Todavia, ressalta-se que essa metodologia não deve ser vista como um fim, mas sim, como um meio para elucidar a teoria vista em sala de aula e elencar novas indagações ao retornar ao âmbito escolar. Ademais, outros valores de grande relevância são acrescidos, como cooperação na realização de trabalhos em equipe, gosto pelo estudo e pela investigação, desenvolvimento da sensibilidade e da percepção, 
estreitamento das relações professor-aluno e aluno-aluno e das relações entre comunidade acadêmica e meio ambiente (SILVESTRE; LIMA; MOREIRA, 2009).

Dessa forma, o Cemitério Público Municipal Nossa Senhora da Conceição, localizado na microrregião norte na cidade de Boa vista - Roraima, situado na zona norte, entre as coordenadas geográficas $\left(2^{\circ} 48^{\prime} 76^{\prime \prime} 9 \mathrm{~N}\right) /\left(60^{\circ} 41^{\prime} 06^{\prime \prime} 6 \mathrm{~W}\right)$, em área urbana, no endereço Rua Paulo Coelho Pereira, n 389, bairro São Vicente passa a ser o objeto de estudo constituído como um espaço não formal para o ensino da geografia (NASCIMENTO, 2016a), ver na Figura 2.

Sendo assim, o cemitério considerado como um espaço público, tornou-se objeto e foco de estudo desde 2013, a partir da elaboração da monografia defendida e aprovada em dezembro de 2016, através do Curso de Graduação em Bacharelado em Geografia pela Universidade Federal de Roraima (UFRR), possibilitando a realização de pesquisas e visitas técnicas in loco.

Figura 02 - Cemitério Público Municipal Nossa Senhora da Conceição, Boa Vista Roraima/RR

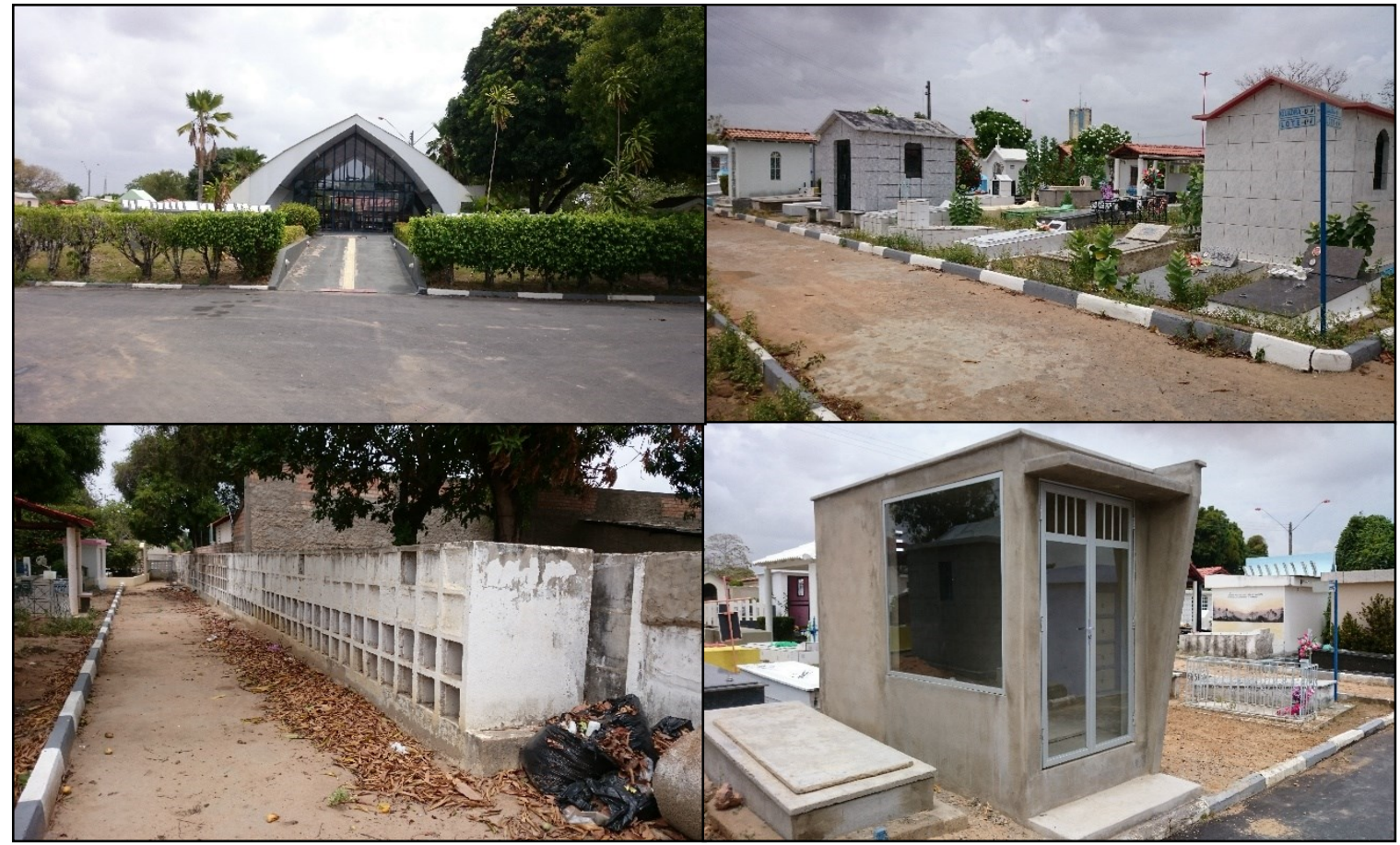

Fonte: fotografias de arquivo pessoal (NASCIMENTO, 2016b) 
No que tange ao uso de ferramentas tecnológicas para facilitar o ensino da geografia, de acordo com Maia et al., (2004) dentre as mídias no processo de ensinoaprendizagem as mais utilizadas são o material impresso, a televisão/vídeo e o rádio.

Conforme Scheer (1999), as opções tecnológicas disponíveis para tornar a escola um mecanismo socializador de informação por meio das mídias pôde-se citar as ferramentas de voz (áudio-educacionais, uso interativo o telefone e de teleconferência, CD-ROM e rádio); impresso (livros, texto complementares, artigos, guias de estudo, entre outros); vídeo (imagens imóveis e imagens ativas em tempo real, combinadas com teleconferência); e dados (uso dos computadores, tablets e internet).

Para o desenvolvimento desta pesquisa utilizou-se o Google Earth Pro ${ }^{4}$ uma ferramenta de navegação muito útil para mediar o ensino geográfico frente as novas tecnologias. Portanto, é possível utilizar desta ferramenta para navegar pelo globo terrestre sem sair de casa ou da escola, conforme na Figura 3, foi possível fazer um passeio virtual pelos cemitérios do Estado de Roraima/RR, possibilitado a visualização do território da morte e a dinâmica da paisagem ao seu entorno, sendo natural ou urbana.

O Google Earth Pro é uma ferramenta que está a serviço do ensino da geografia que possibilita correlacionar com os conteúdos de geografia as tecnologias informacionais. Dentro desse contexto, a geografia e o ensino de forma geral têm a informática como uma das principais mídias utilizadas na atualidade, tendo a particularidade de ser uma mídia multimídia que agrega recursos de diversos tipos como o computador, pendrive, data show, tablet, celulares, lousas interativas, entre outros.

\footnotetext{
${ }^{4}$ É um programa de computador desenvolvido e distribuído pela empresa estadunidense do Google cuja função é apresentar um modelito tridimensional do globo terrestre, construído a partir de mosaico de imagens de satélite obtidas de fontes diversas, imagens aéreas (fotografadas de aeronaves) e GIS 3D. Desta forma, o programa pode ser usado simplesmente como um gerador de mapas bidimensionais e imagens de satélite ou como um simulador das diversas paisagens presentes no Planeta Terra. Com isso, é possível identificar lugares, construções, cidades, paisagens, entre outros elementos. O programa é similar, embora mais complexo, ao serviço também oferecido pelo Google conhecido como Google Maps. É uma aplicação avançada para viajar pelo mundo sem nem ao menos precisar levantar da cadeira. Disponível em: https://pt.wikipedia.org/wiki/Google Earth. Acesso em: 19 dez. 2019.
} 
Figura 03 - Utilizando a ferramenta do Google Earth Pro com a finalidade de fazer um passeio virtual pelos cemitérios do Estado de Roraima/RR

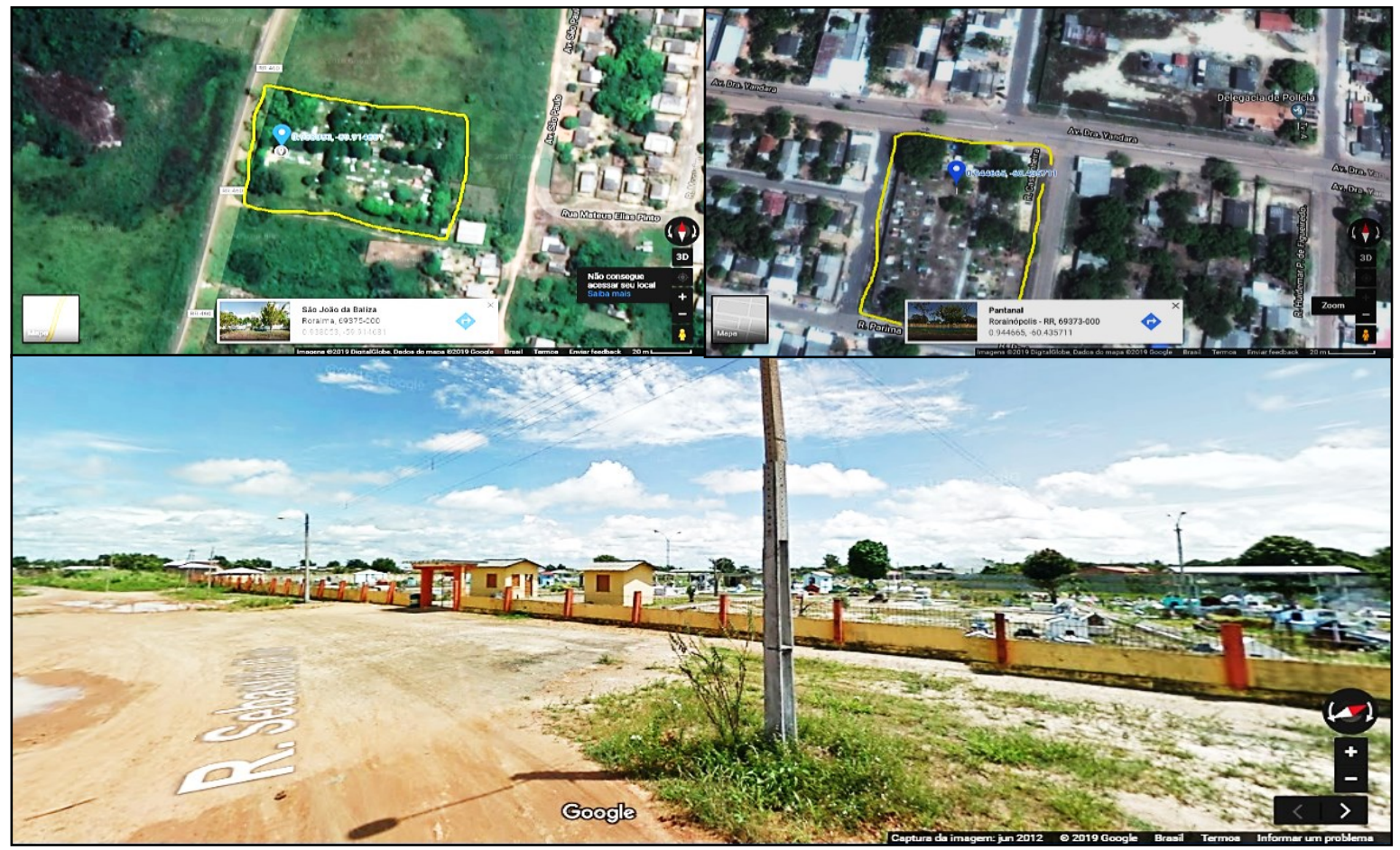

Fonte: imagens retiradas a partir da ferramenta Google Earth Pro (2018)

\subsection{Construção de material didático: maquetes}

É importante mencionar que apesar dos grandes avanços tecnológicos implementados na educação, uma porção significativa dos docentes não desenvolvem suas atividades escolares utilizando como material didático o computador, internet, a TV, DVD, o projetor digital, entre outros. Esses materiais didáticos informacionais funcionam como meio facilitador na aquisição de habilidades básicas, e como ferramentas que pode auxiliar no processo de desenvolvimento cognitivo e humano dos alunos engajados na escola como pode ser observado nesta pesquisa (ROSA, 2013).

Dessa forma, o não uso dessas ferramentas acaba por limitar o docente ao livro didático. Todavia os livros didáticos atualmente são desenvolvidos de forma sistematizada e interacional com os dispositivos digitais, possibilitando ao docente desenvolver diversos materiais e metodologias como aulas interativas, infográficos, slides, quiz, pinturas, 
maquetes, simulados, produção textual, filmes, documentários, vídeo aulas e entre outros, que em muitos casos não são utilizados pelos docentes (MAIA et al., 2004).

Nessa perspectiva, surge a proposta de construção de material didático a partir do uso de maquete que segundo Silva e Muniz (2008, p. 67) o processo de incentivar os alunos a construir maquete "permite uma participação maior deste no processo de aprendizagem, além de dar oportunidade ao educador para perceber o contexto sociocultural em que os estudantes estão inseridos".

Segundo Pitano e Roqué (2015, p. 276) mencionam que “as maquetes despertam os alunos a investigar o espaço vivido, interpretá-lo e contextualizar a Geografia do lugar, promovendo o interesse da participação nas mudanças da sociedade".

Partindo desse princípio, a partir da elaboração da dissertação defendida e aprovada em março de 2019, através do Programa de Pós-Graduação em Desenvolvimento Regional da Amazônia (PPGDRA) do Núcleo de Estudos Comparados da Amazônia e do Caribe (NECAR) pela Universidade Federal de Roraima (UFRR), foi possível a construção de material didático utilizando a maquete como representação espacial do território da morte, ver na Figura 4.

Figura 04 - Maquetes como representação espacial do território da morte

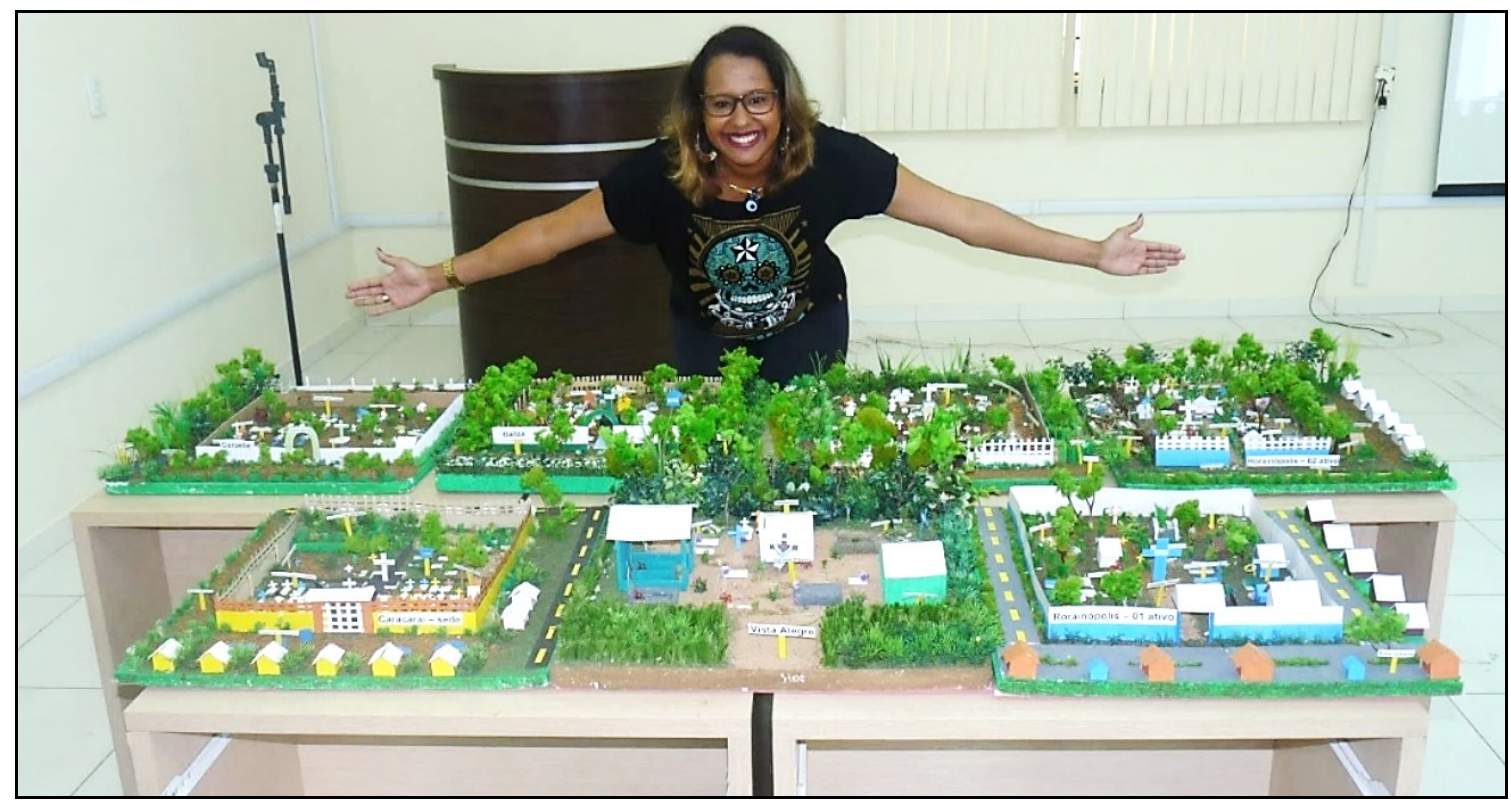

Fonte: fotografia de arquivo pessoal (NASCIMENTO, 2019b) 
O cemitério é um tema importante que contribui na discussão no âmbito de Políticas Públicas. A ciência não pode e nem deve evitar o estudo de temas tabus como as necrópoles (cemitérios), por isso, a relação entre meio ambiente e cemitérios precisa ser conhecida em todas as suas dimensões, principalmente porque o cadáver humano pode ser causa de alterações ambientais e pôr em risco a saúde dos vivos.

Neste sentido, a partir da confecção das maquetes desenvolvidas com base nos municípios de Caracaraí-RR localizado na Mesorregião Sul; Rorainópolis-RR, CaroebeRR, São João da Baliza-RR e São Luíz-RR localizados na Microrregião Sudoeste da Região Sul do Estado de Roraima no período de 1995 a 2018 pesquisados a partir da dissertação, foi possível representar em escala de 1:250cm os cemitérios que compõe a Região Sul do Estado de Roraima.

Figura 05 - Representação espacial do território da morte: maquetes confeccionadas em escala de 1:250 cm dos cemitérios da Região Sul do Estado de Roraima/RR

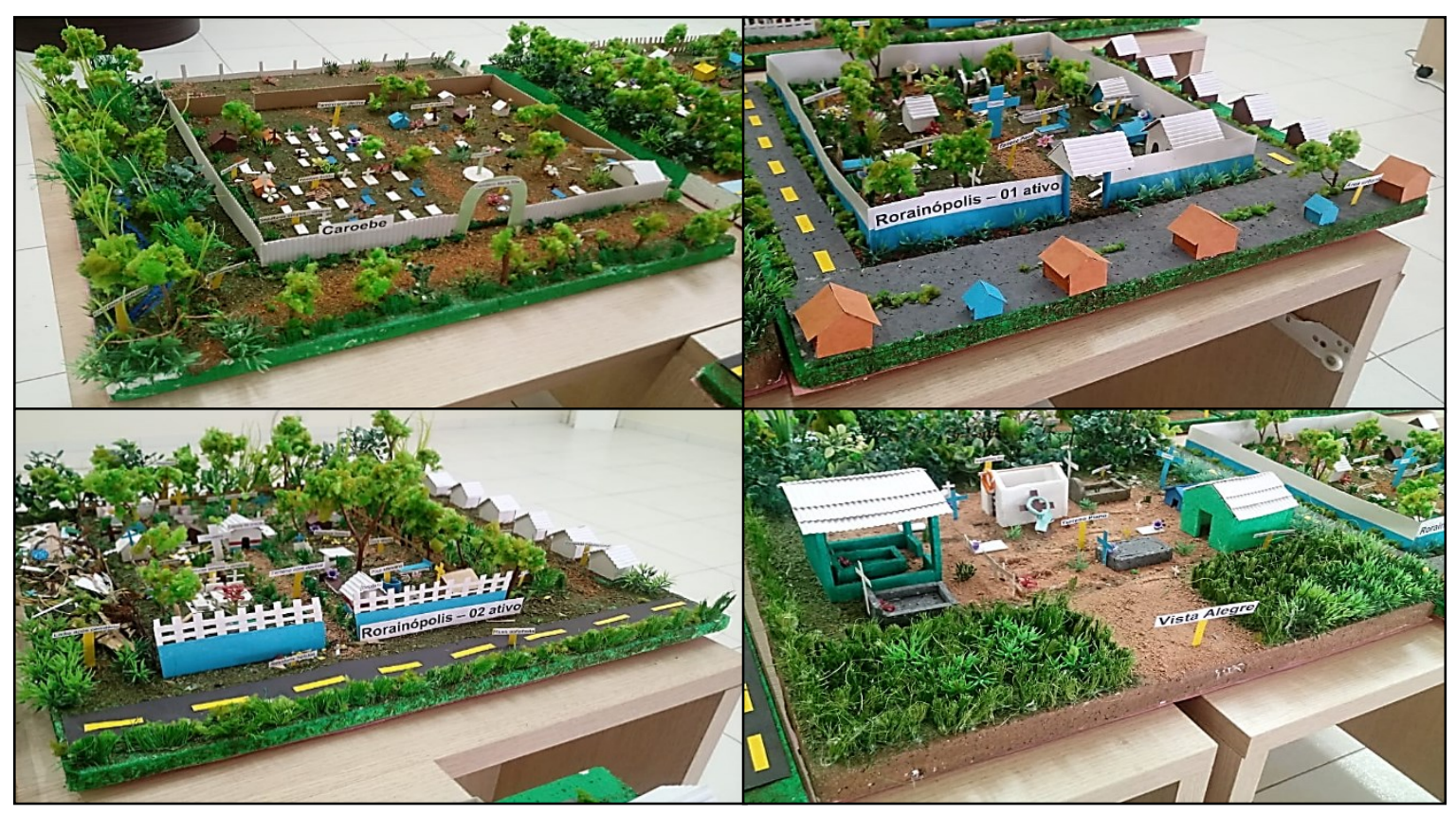

É importante mencionar que as maquetes trazem detalhes internos e externos do espaço geográfico dos cemitérios, apresentando elementos tais como: localização geográfica; diferenciando das áreas urbana e rural; a presença da vegetação na parte interna e externa - em áreas urbanas e rurais; a presença de animais (cavalo e boi) 
encontrados circulando dentro do cemitério - em área rural; corpo hídrico presente ao lado de um dos cemitérios - em área rural; residências ao entorno do cemitério em área urbana; cemitério próximo a lixeira pública - em área urbana; e resíduos sólidos gerados na construção das sepulturas no interior do cemitério - em áreas urbanas e rurais, ver na Figura 5.

Nesse contexto, Pitano e Roqué (2015, p. 276) ressaltam que o uso de maquetes “propicia a valorização local e a solução de problemas, desde o espaço físico ao social, ligando o ensino da disciplina ao cotidiano do aluno, pois possibilita mostrar a organização e a ocupação do espaço, além da interação com o meio representado na maquete".

\subsection{Desenhos: croquis}

A educação no decorrer da sua história passou por diversas mudanças e quebra de paradigmas deixando de ser tradicionalista para se tornar uma educação mais lúdica. Nesse contexto, Almeida (1984) ressalta que a educação mudou impulsionada pela pedagogia de Piaget, que afirma que a ludicidade é de fundamental importância da para as crianças se desenvolverem, visto que a infância é o momento em que se inaugura o processo de socialização na vida do indivíduo, devendo permanecer este processo ao longo de toda a sua vida.

A escola dessa forma tornou-se um lugar de transformação de ensino e socialização para as crianças onde através das brincadeiras, jogos, pintura, colagem, esculturas, desenhos e músicas, os alunos constroem seu próprio conhecimento (PINTO, 1997). Nesse contexto, o lúdico no âmbito escolar conquistou seu espaço, pois alcançou muitos objetivos como a possibilidade de novas metodologias de ensinos.

Diante desse cenário Montagnini et al., (2009) ressaltam que o lúdico possibilita a introdução de diversas linguagens no processo de ensino aprendizagem, como o gesto, a palavra, o desenho, a pintura, a colagem, as construções tridimensionais, a imaginação e a música. Portanto, o desenho como linguagem universal, é adepto pelos alunos dos ensinos fundamentais e médio, o uso desta técnica vem desde a 
primeira infância - tanto de forma não formal como formal, o desenho acaba sendo um instrumento para a elaboração de material didático que pode ser muito explorado para o desenvolvimento dos conteúdos de geografia, e os croquis são desenhos que podem ser confeccionados "a mão livre" ou digitais (utilizando de ferramentas tecnológicas e programas específicos para a confecção do desenho). 0 croqui do cemitério do município de Mucajaí-RR foi elaborado no formato digital, utilizando do próprio Word na confecção dos detalhes e elementos que fazem parte da estrutura interna e externa do cemitério, ver na Figura 6.

Figura 06 - Croqui: Planta de situação, locação do cemitério e seu entorno - Cemitério Público Urbano Nossa Senhora das Graças de Mucajaí - Roraima/RR.

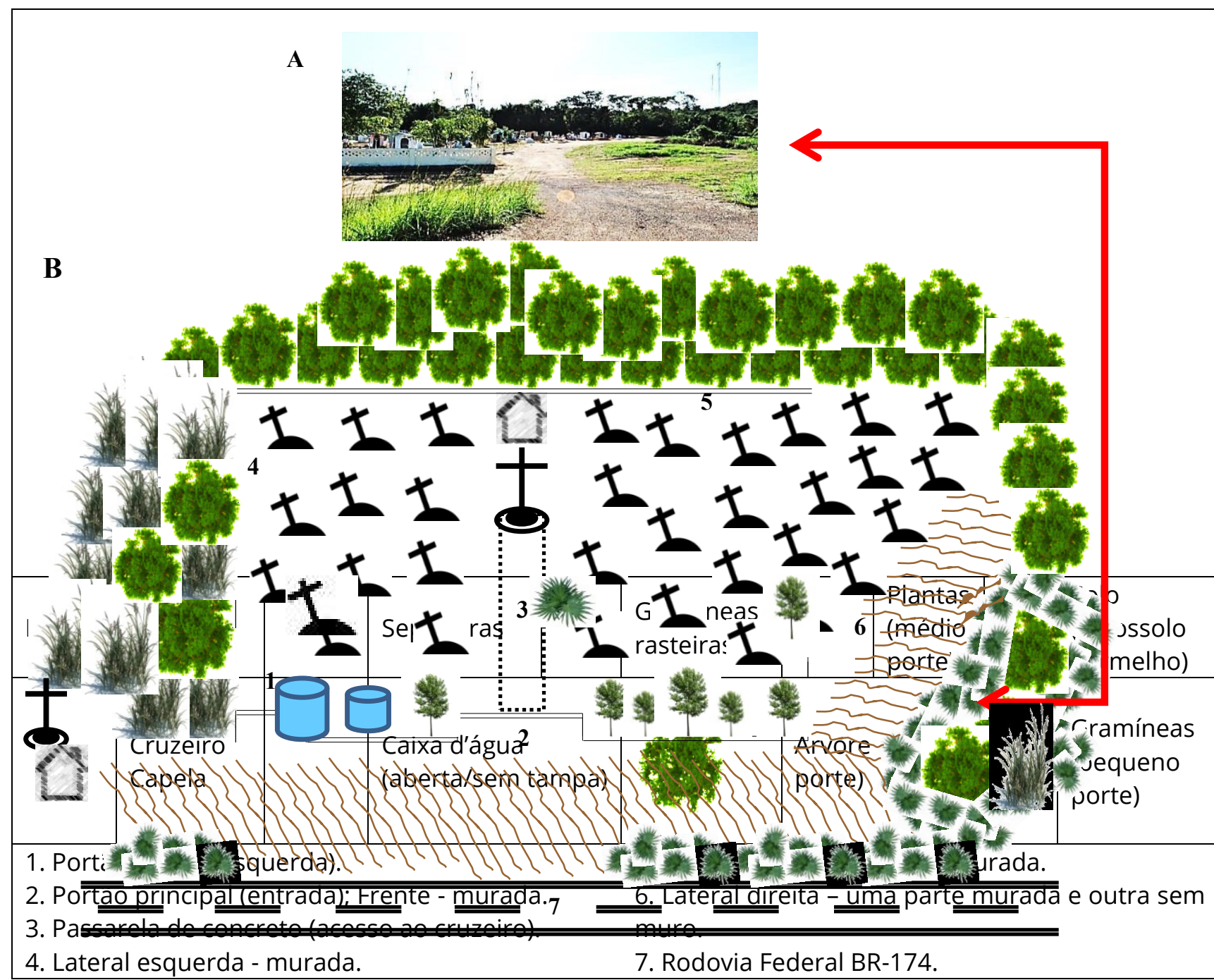

Figura (A): Foto da lateral direita do cemitério e sem muro;

Figura (B): Croqui - Planta de situação e locação do cemitério e seu entorno.

Fonte: NASCIMENTO (2015; 2019a) 
Sendo assim, o uso do croqui é fundamental para o ensino da geografia, pois permitem criar "esquemas gráficos de arranjos espaciais, esboços traçados no papel em observações de campo, como formas de estudo e registro das paisagens, dos lugares, das extensões, distribuições e localizações" (MIRANDA, 2005, p. 56).

Neste sentido, trazendo os pontos convergentes e correlacionando-os com as necrópoles com o ensino de geografia, o estudo identifica que diversas temáticas podem ser desenvolvidas como os aspectos da paisagem; o relevo; o clima; as transformações da paisagem natural, população; urbanização; as questões sociais; políticas; espaciais; econômicas e culturais que contemplam principalmente o âmbito dos espaços urbanos, apresentados pelas inter-relações entre si, mostrando que a temática da morte envolvendo o espaço físico o cemitério pode ser aplicada e utilizada como espaço não formal para o ensino da geografia.

\section{CONSIDERAÇÕES FINAIS}

Considerando que a educação formal compreende um ensino curricular formado por um conjunto de conteúdos previamente estipulados dentro de uma proposta curricular marcada pelas práticas pedagógicas ofertadas e desenvolvidos pela escola secular. Enquanto que, a educação não formal compreende o ensino ofertado por outras entidades que fazem uso de diversos métodos, procedimentos e sistemas que vão além dos padrões da educação formal visando preencher as lacunas deixadas pela escola que não consegue atender todas as demandas atuais.

Nessa perspectiva, surge a proposta do ensino a partir dos espaços não formais de ensino direcionado para o ensino da geografia. Partindo desse princípio, a pesquisa volta-se aos seus objetivos para apresentar o cemitério como um espaço público não formal para o ensino da geografia.

Dessa forma, para mostrar através da metodologia de aula de campo que o cemitério pode ser utilizado como um espaço público não formal para o ensino da geografia, a pesquisa enfatiza que a aula de campo possibilita ao professor e alunos o 
contato com o objeto de estudo proporcionado a aplicação prática dos conteúdos assimilados em sala de aula. A partir dessa metodologia o docente leva a aula para além das quatro paredes da sala de aula e desperta o discente a conhecer e ter contato com o conteúdo na prática, possibilitando que o mesmo possa construir suas próprias concepções mediadas pelo professor.

E ao apresentar o cemitério como esse espaço público não formal para o ensino da geografia observa-se que várias temáticas do ensino da disciplina de geografia podem ser aplicados fazendo análises a partir da paisagem, o uso dos espaços, das desigualdades sociais, das transformações da paisagem urbana no que tange aos aspectos socioeconômicos, socioambientais, políticos, históricos e culturais, estabelecendo um apoio e auxílio na condução da aula.

No que tange destacar as ferramentas tecnológicas que podem ser aplicadas em sala de aula utilizando o cemitério como espaço público não formal para o ensino da geografia, a pesquisa destaca o Google Earth Pro como uma ferramenta de navegação muito útil para mediar o ensino geográfico frente as novas tecnologias. O Google Earth Pro é uma ferramenta que está a serviço do ensino possibilitando correlacionar com os conteúdos de geografia as tecnologias informacionais. E quando relacionado à temática das necrópoles, a mesma pode ser utilizada com a finalidade de fazer um passeio virtual pelos cemitérios de qualquer lugar do planeta, mostrando a paisagem fúnebre do lugar e sua relação com a ocupação do espaço urbano, identificando se nas proximidades há nascentes de rios ou lençol freático.

No que se refere a descrever os materiais didáticos que podem ser produzidos utilizando o cemitério como espaço público não formal para o ensino da geografia, a pesquisa ressalta a produção de duas ferramentas: maquetes e croquis. A primeira ferramenta desperta os alunos a investigar o espaço vivido, conduzindo-os a interpretá-lo e contextualizar a Geografia do lugar, promovendo o interesse da participação nas mudanças da sociedade e o contexto sociocultural em que os estudantes estão inseridos. A segunda ferramenta possibilita aos alunos o desenvolvimento das ferramentas cartográficas possibilitando que os mesmos criem 
esquemas gráficos de arranjos espaciais, proporcionando a elaboração de esboços traçados no papel em observações de campo, como formas de estudo e registro das paisagens, dos lugares, das extensões, distribuições e localizações.

Sendo assim, retornando a questão problema da pesquisa de como o cemitério pode ser objeto de estudo da geografia de maneira que esse conteúdo possa ser explorado e contextualizado com o saber geográfico dentro e fora de sala de aula. E como associar a educação não formal com os conhecimentos da geografia a partir do cemitério como objeto de estudo. A pesquisa mostra que a temática das necrópoles pode ser aplicada e utilizada como espaço não formal de ensino da geografia em diversas temáticas por meio da aula de campo, bem como na produção de maquetes e croquis, e no uso de ferramentas tecnológicas informacionais como, por exemplo, o Google Earth Pro.

\section{REFERÊNCIAS}

ALMEIDA, L. M. A. de.; RIGOLIN, T. B. Fronteiras da Globalização: o mundo natural e o espaço humanizado $-1^{\circ}$ ano, Geografia (Ensino Médio). v. 1., 2. ed. São Paulo, SP: África, 2013.

ALMEIDA, P. N. Dinâmica Lúdica: jogos pedagógicos. São Paulo, SP: Loyola, 1984.

BARDIN, L. Análise de Conteúdo. São Paulo, SP: Edições 70, 2011.

BRASIL. Parâmetros Curriculares Nacionais (PCN's). Geografia: temas transversais. Secretaria de Educação Fundamental. Brasília: MEC/SEF, 2001. Disponível em: http://portal.mec.gov.br. Acesso em 15 de jan de 2019.

BRASIL. Parâmetros Curriculares Nacionais (PCN's). História, Geografia. Secretaria de Educação Fundamental. Brasília: MEC/SEF, 1997. Disponível em: http://portal.mec.gov.br. Acesso em 15 de jan de 2019.

BRASIL. Parâmetros Curriculares Nacionais (PCN's). Introdução aos Parâmetros Curriculares Nacionais (1997). Brasília: MEC, 1997. Disponível em: http://portal.mec.gov.br. Acesso em 15 de jan de 2019.

CALDEIRA, T. Cidade de Muros. São Paulo: Edusp, 2000. 
CASCAIS, M. das G. A.; TERÁN, A. F. Educação formal, informal e não formal na educação em ciências. Revista Ciência em Tela, Rio de Janeiro, v. 7, p. 1-10, 2014.

CASTROGIOVANNI, A. C. Para entender a necessidade de práticas prazerosas no ensino de Geografia na pós-modernidade. In: REGO, N. Geografia: práticas pedagógicas para o ensino médio. Porto Alegre, RS: Artmed, 2007.

COSTA, M. N. de M. G.; ARAÚJO, R. P. de. A importância da visita técnica como recurso didático metodológico. Um relato na prática do IF Sertão Pernambucano. In: CONGRESSO NORTE E NORDESTE DE PESQUISAS E INOVAÇÕES, Anais ...., n. 3., 2012, Palmas - TO, 2012.

CURY, C. R. J. A Educação Básica no Brasil. Revista Educação \& Sociedade, São Paulo - SP, v. 23., n. 80., p. 168-200, 2002.

FERREIRA, A. A.; RODRIGUES, S. X. C.; JESUS, J. N. de. A importância da prática de ensino em Geografia. In: EDIPE - ENCONTRO ESTADUAL DE DIDÁTICA E PRÁTICA DE ENSINO, Anais ..., v. 4., Quirinópolis - GO, 2011.

GIL, A. C. Como Elaborar Projetos de Pesquisa. 5. ed. São Paulo: Atlas, 2010.

GIL, A. C. Métodos e Técnicas de Pesquisa Social. 6. ed. São Paulo, SP: Atlas, 2008.

GOHN, M. da G. Movimentos sociais na contemporaneidade. Revista Brasileira de Educação, v. 16, n. 47, p. 333-361, 2011.

GOHN, M. da G. Educação não formal: um novo campo de atuação. Revista Ensaio Avaliação e Políticas Públicas em Educação, Rio de Janeiro - RJ, v. 6., n. 21., p. 511 526, 1998.

JACOBUCCI, D. F. C. Contribuições dos espaços não-formais de educação para a formação da cultura científica. Revista em Extensão, Minas Gerais - GO, v. 7., n. 1., 2008.

KLIMEK, R. L. C. Como aprender Geografia com a utilização de jogos e situações problema. In: PASSINI, E. Y.; PASSINI, R.; MALYSZ, S. T. Prática de ensino de Geografia e estágio supervisionado. São Paulo, SP: Contexto, 2007.

LAKATOS, E. M.; MARCONI, M. de A. Fundamentos de metodologia científica. 6. ed. 5. reimp. São Paulo: Atlas, 2007.

LEON LUCAS, A. Os cemitérios no bairro fragata: uma relação entre o antigo e o contemporâneo. 2006, 105p. Monografia (Pós-Graduação em Artes) - UFP, Pelotas-RS.

LIMA, F. S. O conhecimento geográfico. Salvador, BA: Universidade do Estado da Bahia - Departamento de Ciências Humanas - Campus VI - Caetité, 2002. 
LUCCI, E. A.; BRANCO, A. L. Geografia: homem e espaço, $6^{\circ}$ ano. Geografia (Ensino Fundamental). 26. ed. São Paulo, SP: Saraiva, 2015.

LUCCI, E. A.; BRANCO, A. L. Geografia: homem e espaço, $7^{\circ}$ ano. Geografia (Ensino Fundamental). 24. ed. São Paulo, SP: Saraiva, 2015.

LUCCI, E. A.; BRANCO, A. L. Geografia: homem e espaço, $8^{\circ}$ ano. Geografia (Ensino Fundamental). 27. ed. São Paulo, SP: Saraiva, 2015.

LUCCI, E. A.; BRANCO, A. L. Geografia: homem e espaço, $9^{\circ}$ ano. Geografia (Ensino Fundamental). 27. ed. São Paulo, SP: Saraiva, 2015.

LUCCI, E. A.; BRANCO, A. L. Geografia: homem e espaço. Geografia (Ensino Fundamental). 24. ed. São Paulo: Saraiva, 2015.

MAIA, M. de C.; MENDONÇA, A. L.; LEITE, J. C. A aplicação de tecnologias educacionais num curso a distância: o caso GVnext. FGV-EAESP. Disponível em: http://www.abed.org.br. Acesso em 02 de dez de 2019.

MARANDINO, M.; SELLES, S. E.; FERREIRA, M. S. Ensino de Biologia: histórias e práticas em diferentes espaços educativos. São Paulo: Cortez, 2009. (Coleção Docência em Formação. Série Ensino Médio).

MARCONI, M. de A.; LAKATOS, E. M. Técnicas de Pesquisa. 5. ed. São Paulo, SP: Atlas, 2006

MARTINI, A.; GUIMARÃES, D. L.; MAZZUCO, R. I. D. L. G.; MUNIZ, S. S. Cemitério Jardim da Paz como patrimônio histórico, cultural, material e imaterial. Revista de Ciências Humanas e Sociais - Missões, Rio Grande do Sul - RS, v. 3., n. 2., 2018.

MIRANDA, S. L. O lugar do desenho e o desenho do lugar no ensino de geografia: contribuição para uma geografia escolar crítica. 2005, 158p. Tese (Doutorado em Geografia) - Universidade Estadual Paulista, Rio Claro-SP.

MONEZI, C. A.; FILHO, C. O. Corrêa de Almeida. A visita técnica como recurso metodológico aplicado ao curso de engenharia. In: CONGRESSO BRASILEIRO DE ENSINO DE ENGENHARIA, Anais ..., v. 33., 2005, Campina Grande - PB, 2005.

MONTAGNINI, R. C.; CAVA, L. C. C.; ANDRADE, K. G. Ensino das artes e música: pedagogia. São Paulo, SP: Pearson Prentice Hall, 2009.

MOURA, C. A. de. Visita técnica realizada no viveiro de mudas da Mineração Onça Puma com o propósito de inserção de valores ambientais na formação acadêmica. Centro Nacional de Educação a Distância. Porto Alegre, RS: CENED, 2008. Disponível em: http://www.cenedcursos.com.br. Acesso em 02 de dez de 2019. 
MOURA, M. T. J. A. de. Escola e Museu de Arte: uma parceria possível para a formação artística e cultural das crianças. In: $28^{\mathrm{a}}$ REUNIÃO ANUAL DA ANPED, Anais ..., n. 1., v. 18., Rio de Janeiro - RJ, 2005.

NASCIMENTO, F. L. Análise descritiva do cemitério público municipal urbano localizado na Região Norte no Estado de Roraima-RR. 2016a, 140p. Monografia (Trabalho de Conclusão de Curso de Graduação em Geografia) - Universidade Federal de Roraima, Boa Vista-RR.

NASCIMENTO, F. L. Arquivo da pesquisa de campo: Croqui - Planta de situação, locação do cemitério e seu entorno - Cemitério Público Urbano Nossa Senhora das Graças de Mucajaí - Roraima/RR (CD-ROM). Boa Vista, RR, 2019a.

NASCIMENTO, F. L. Arquivo da pesquisa de campo: fotografias das maquetes confeccionadas em escala de $1: 250 \mathrm{~cm}$ dos cemitérios da Região Sul do Estado de Roraima/RR (CD-ROM). Boa Vista, RR, $2019 b$.

NASCIMENTO, F. L. Arquivo da pesquisa de campo: fotografias do Cemitério Público Municipal Nossa Senhora da Conceição, Boa Vista - Roraima/RR (CD-ROM). Boa Vista, RR, $2016 b$.

NASCIMENTO, F. L. Arquivo da pesquisa de campo: fotografias do Cemitério Público Urbano Nossa Senhora das Graças de Mucajaí - Roraima/RR (CD-ROM). Boa Vista, RR, 2015.

NASCIMENTO, F. L. Cemitérios públicos urbanos municipais da região sul do estado de Roraima (1995-2018). 2019c, 412p. Dissertação (Mestrado em Desenvolvimento Regional da Amazônia) - Universidade Federal de Roraima, Boa Vista-RR.

PACHECO, A. Meio Ambiente e Cemitérios. São Paulo, SP: Editora SENAC São Paulo, 2012.

PASSERINI, G. A. O estágio supervisionado na formação inicial do professor de Matemática na ótica de estudantes do curso de licenciatura em Matemática da UEL. 2007. Dissertação (Mestrado em Ensino de Ciências e Educação Matemática) Universidade Estadual de Londrina, Londrina-PR.

PINTO, M. A infância como construção social. Minho-Portugal: Centro de Estudos da Criança, 1997.

PITANO, S, C.; ROQUÉ, B. B. O uso de maquetes no processo de ensino-aprendizagem segundo licenciados em Geografia. Revista Educação Unisinos, São Leopoldo - RS, n. 19., p. 273-282, 2015. 
PRODANOV, C. C.; FREITAS, E. C. de. Metodologia do trabalho científico: métodos e técnicas da pesquisa e do trabalho acadêmico. 2. ed. São Paulo, SP: Feevale, 2013.

RAMOS, P.; RAMOS, M. M.; BUSNELLO, S. J. Manual prático de metodologia da pesquisa: artigo, resenha, projeto, TCC, monografia, dissertação e tese. Blumenau, SC: Acadêmica, 2005.

ROSA, R. Trabalho docente: dificuldades apontadas pelos professores no uso das tecnologias. Revista Encontro de Pesquisa em Educação, Uberaba - MG, v. 1., n. 1., p. 214-227, 2013.

SANTOS, M. O Espaço do Cidadão. São Paulo, SP: Nobel, 1987.

SANTOS, S. C. dos. O processo de ensino-aprendizagem e a relação professor-aluno: aplicação dos "sete princípios para a boa prática na educação de ensino superior". Revista Caderno de Pesquisas em Administração, São Paulo - SP, v. 8., n. 1., 2001.

SCHEER, S. Multimeios em EAD. In: Educação à distância: um debate multidisciplinar. Curitiba: UFPR, 1999.

SILVA, A. M. B. da.; BATISTA, E. A. C. da.; BEZERRA, J. dos S. Influência da educação infantil na formação da personalidade das crianças. 2016. Disponível em: https://portal.fslf.edu.br/wp-

content/uploads/2016/12/Influencia_da_educacao_infantil_na_formacao_da_personali dade.pdf. Acesso em 15 de jan de 2019.

SILVA, M. C. da. A concepção de professores do Ensino Médio sobre a importância da disciplina de Geografia para a formação de seu aluno. 2004, 148p. Monografia (Especialização em Prática Docente) - Universidade do Extremo Sul Catarinense, Criciúma-SC.

SILVA, V. da.; MUNIZ, A. M. V. A geografia escolar e os recursos didáticos: o uso das maquetes no ensino-aprendizagem da geografia. Revista de Estudos Geoeducacionais - Geosaberes, Fortaleza - CE, v. 3., n. 5., p. 62-68, jan/ jun. 2012.

SILVA, V.; MUNIZ, A. M. V. A geografia escolar e os recursos didáticos: o uso das maquetes no ensino-aprendizagem da geografia. Revista de Estudos Geoeducacionais - Geosaberes, Fortaleza - CE, v. 3., n. 5., p. 62-68, 2012.

SILVESTRE, D.; OLIVEIRA, I. M. C. F. de L.; MOREIRA, M. de F. A. R. O trabalho de campo como prática pedagógica no ensino da Geografia. Centro de Ciências Exatas e da Natureza. Paraíba, PB: Departamento de Geociências/PRODOCÊNCIA, 2009.

TAVOLARI, B. O direito à cidade: a trajetória de um conceito. Revista Novos estudos CEBRAP, v. 35, n. 1, p. 93-109, 2016. 
TOMITA, L. M. S. Trabalho de Campo como instrumento de Ensino em Geografia. Revista do Departamento de Geociências - Geografia, Londrina - PR, v. 8., n. 1., p. 13-15, 1999.

VAINE, T. E.; LORENZETTI, L. Potencialidades dos espaços não-formais de ensino para a alfabetização científica: um estudo em Curitiba e região metropolitana. In: ENCONTRO NACIONAL DE PESQUISA EM EDUCAÇÃO EM CIÊNCIAS - XI, Anais ..., 2017. 